\title{
"Baje usted la voz en sus discursos y en sus escritos": Juana Paula Manso e as tentativas de silenciar uma mulher pública na Argentina oitocentista
}

\author{
Deise Cristina Schell ${ }^{1}$
}

\begin{abstract}
Resumo: As mulheres tiveram possibilidades de atuação bastante restritas fora da esfera doméstica na Argentina oitocentista. Ainda assim, Juana Paula Manso participou de diferentes campos da esfera pública. Este artigo demonstra as formas de silenciamento algumas sutis, outras violentas - que tentaram lhe impor durante sua trajetória intelectual na Buenos Aires da segunda metade do século XIX. Também interessa-nos analisar as respostas de Manso às investidas que sofreu. $O$ enfoque temporal é a década de 1860, quando a intelectual se inseriu de maneira mais evidente nos espaços letrado e institucional argentinos e interveio na defesa de suas ideias, de seus projetos e da publicação de suas produções. As principais fontes utilizadas neste estudo são as correspondências trocadas entre Juana Paula Manso e Domingo Faustino Sarmiento, textos de Juan María Gutiérrez e Enrique María de Santa Olalla e os escritos da letrada publicados no "Compendio de la Historia de las Provincias Unidas del Río de la Plata" e nos periódicos "La Flor del Aire", "La Siempre-Viva" e "Anales de la Educación Común".
\end{abstract}

Palavras-chave: Juana Paula Manso; mulher pública; silenciamento

\section{"Baje usted la voz en sus discursos y en sus escritos": Juana Paula Manso and the efforts of silencing a public woman in 19th century Argentina}

\begin{abstract}
Women had very limited possibilities of acting outside the domestic sphere in the 1800s Argentina. Despite that, Juana Paula Manso played a role in some fields of public space. This article presents the silencing methods - some subtle, other violent that some attempted to impose onto her during her intellectual trajectory in the second half of the 19th century in Buenos Aires. It also introduces Manso's response to those attempts to silence her. We analyzed the 1860 s when the intellectual entered Argentinean's scholar and institutional spaces and defended her ideas and her projects.
\end{abstract}

\footnotetext{
${ }^{1}$ Doutora em História. Professora do Programa de Pós-Graduação em História da Universidade do Vale do Rio dos Sinos. Apoio Financeiro Edital FAPERGS 04/2019 - Auxílio Recém-Doutor-ARD. Projeto de Pesquisa "Juana Paula Manso, historiadora: gênero e produção do conhecimento histórico na Argentina oitocentista (1852-1875)". ORCID 0000-0001-7937-0490.E-mail: deiseschell@unisinos.br.
} 
Our historical sources are letters exchanged between Juana Paula Manso and Domingo Faustino Sarmiento, papers by Juan María Gutiérrez and Enrique María de Santa Olalla, and Manso's works published in "Compendio de la Historia de las Provincias Unidas del Río de la Plata", "La Flor del Aire", "La Siempre-Viva", and "Anales de la Educación Común".

Keywords: Juana Paula Manso; public women; silencing

Artigo recebido em: 17/03/2021

Artigo aprovado para publicação em: 30/07/2021

\section{Introdução}

Entre 1866 e 1867, Domingo Faustino Sarmiento escreveu uma série de correspondências para Juana Paula Manso. Nas missivas, entre outros assuntos, havia um tópico específico: o intelectual repercutia com sua amiga e interlocutora os ataques que ela havia sofrido naqueles anos por escrever e falar publicamente. Uma das investidas contra Manso foi uma carta dirigida à letrada redigida pelo professor primário Enrique María de Santa Olalla, que fora enviada a um jornal bonaerense para que circulasse. Em agosto de 1866, o escrito do maestro foi publicado, em que, como se verá adiante neste artigo, entre outros impropérios, ele afirmava que sua colega de profissão "dava las muestras visibles de desorganización cerebral" (SANTA OLALLA apud VELASCO Y ARIAS, 1937, p. 324). As outras agressões à Juana Manso ocorreram ao longo daqueles dois anos enquanto ela fazia "lecturas públicas", conferências que, então, realizava sobre diversos temas de seu conhecimento e interesse. Algumas destas suas falas foram antecipadas por censura ou intercaladas por gritos, ofensas, tijolos sendo jogados contra as paredes do edifício em que ocorriam e até por substâncias mal-cheirosas sendo arremessadas nas vestes da conferencista. Esses episódios também serão retomados e detalhados neste texto. Importa-me, por enquanto, falar da reação de Sarmiento a tais eventos: à medida em que Manso noticiava o que ocorria consigo na Argentina, o sanjuanino, que naquele momento vivia nos Estados 
Unidos, respondia-a com palavras de apoio. Ele tentava, de diversas formas, consolá-la e prestar-lhe solidariedade (BATTICUORE, 2005, p. 139), sustentando o argumento de que os portenhos - diferentemente dos norte-americanos e dos europeus - não estavam acostumados com a presença de uma mulher inteligente como ela ocupando os espaços públicos. Em uma das cartas, datada em 11 de junho de 1867, dizia:

Me entristecen sus desahogos, contra la presión que experimenta, ojalá por ser mujer. [...] Vive en mi hotel la editora y autora de un periódico de costumbres, que le da renta sobrada para vivir y hacer de vez en cuando viajes á Europa. A una mujer escribiera en nuestros países con menos acierto, bastaría que fuese tan raro el hecho, para alentarlo, en lugar de hacerle insoportable la existencia con punzadas de mal tono. (SARMIENTO, 1899, p. 207)

Já em outra, de 15 de outubro do mesmo ano, perguntava a Manso: “¿Sabe Ud. de otra argentina que ahora ó antes haya escrito, hablado ó publicado, trabajando por una idea útil, compuesto versos, redactado un diario?” (SARMIENTO, 1899, p. 217). Em seguida, emendava: “Una mujer pensadora es un escándalo. ;Ay! pues, de aquel por quien el escándalo venga! y Ud. ha escandalizado á toda la raza" (SARMIENTO, 1899, p. 217). Se por um lado Sarmiento reconhecia o valor da atuação e da produção de Juana Manso $^{2}$ e que a violência acometida contra ela se dava por uma questão de gênero, acabava por reafirmar, por outro, a excentricidade dela no contexto argentino, como se ela fosse a única intelectual e escritora pública (e interlocutora de um sujeito como ele) possível naquele espaço e àquele tempo ${ }^{3}$; como se ela própria fosse, por sua

\footnotetext{
${ }^{2}$ Inclusive fazendo isso publicamente, como se verá neste artigo.

${ }^{3}$ Há outros momentos desta série de correspondências em que Sarmiento faz afirmações neste sentido, como ao escrever, em 18 de julho de 1866, que Juana Manso era "la única mujer que entre un millón de habitantes rinde culto á la inteligencia" (SARMIENTO, 1899, p. 140). Ressalto, no entanto, que na década de 1860 - e mesmo antes, se pensarmos em iniciativas como o jornal feminino "La Camelia" de 1852 -, existiam outras mulheres argentinas que escreviam publicamente, além da personagem. Juana Manuela Gorriti, ainda que vivesse entre o Peru e a Bolívia, publicou sua primeira obra, "Sueños y Realidades", em 1865. Não por acaso, um ano depois, no sarau de inauguração da Biblioteca Pública de Chivilcoy, iniciativa de Manso como demonstrarei adiante, uma de suas filhas realizou a leitura de um texto de Gorriti intitulado "Una hora de coquetería", saído no periódico "La Revista de Buenos Aires" (LEWKOWICZ, 2000, p. 183). Outro exemplo é a escritora Eduarda Mansilla de Garcia, que, naquele tempo, já colaborava em diversas publicações, dentre as quais "La Flor del Aire", semanário do qual Juana Manso fez parte, como também abordarei ao longo do texto. Quantas outras mulheres
} 
suposta excepcionalidade, a causa essencial do problema - e não as ações de seus detratores. Não é de surpreender, assim, que o conselho derradeiro sugerido por Sarmiento à sua parceira de projetos e pensamentos para dar fim aos ataques que sofria tenha sido o seguinte: “Baje Ud. pues, la voz en sus discursos y en sus escritos, á fin de que no llegue hasta aqui el sordo rumor de la indisciplinada turba" (SARMIENTO, 1899, p. 222).

Apesar de vinda de um amigo com prováveis boas intenções, a sugestão de "baixar a voz" era mais uma das diferentes formas de demover Manso da ideia de ocupar o espaço público bonaerense da maneira que fazia naquela década de 1860, pautando-o com sua presença e com as temáticas sobre as quais falava e escrevia. É preciso lembrar, como já se pode imaginar, que as possibilidades de participação das mulheres na arena pública e na vida cidadã eram bastante restritas na Argentina do século $\mathrm{XIX}^{4}$. No entanto, se por um lado as esferas de ação de homens e mulheres estivessem bem demarcadas - sendo o espaço privado considerado natural e incondicionalmente feminino -, isso não foi suficiente para evitar que algumas delas, como Juana Paula Manso, interviessem publicamente. Assim, a trajetória da personagem na Argentina pós-Caseros é reveladora das fissuras existentes em um discurso aparentemente rígido que sustentava que, enquanto as mulheres desempenhavam as atividades domésticas, a tarefa de construção da nação estava apenas nas mãos de homens cultos (MASIELLO, 1989, p. 267). Estas fissuras, no

\footnotetext{
"inteligentes" e "pensadoras" deveriam existir na Argentina oitocentista, mas que se manifestavam sob pseudônimos ou não conseguiam ultrapassar as barreiras que lhes eram impostas pelas persistentes formas de silenciá-las?

${ }^{4}$ Segundo Dora Barrancos, na segunda metade do oitocentos, o culto à mãe virtuosa e à esposa fiel e cuidadora mantinha-se como um valor fundamental da sociedade argentina: "la vida familiar fungía como la puerta de entrada al ágora del orden republicano, y como los varones dispensaban la participación femenina, hacian crer que la antecámara de la sociedad, el hogar, era lo más importante y que ahí reinaban las mujeres" (2010, p. 94). Agravando essa situação, o código civil de 1869, elaborado por Dalmacio Vélez Sarsfield e promulgado durante a presidência (justamente) de Sarmiento, determinava a incapacidade relativa da mulher casada, colocando-a sob a tutela do marido e, desta forma, "en una posición de inferioridad aún más grave que si se tratara de la condición infantil" (BARRANCOS, 2010, p. 101).
} 
entanto, não eram suficientes para que a intelectual pudesse atuar sem ser atacada, constrangida ou mesmo depreciada ou desprezada. Como demonstrarei neste artigo, por conta das atividades letradas e institucionais que assumiu a partir de 1859 e ao longo dos anos 1860, entre pedidos como o de Sarmiento e agressões morais e físicas como as relatadas inicialmente, outras formas de tentar silenciar Juana Paula Manso, por vezes mais sutis e veladas, também ocorreram. Ela, no entanto, jamais se calou, como se verá.

\section{Juana Paula Manso: uma mulher no espaço público e as tentativas de silenciá-la}

Juana Paula Manso lia, escrevia e convivia com o mundo público desde a sua juventude, vivenciada em meados do século XIX em Montevidéu e no Rio de Janeiro, cidades para onde sua família unitária exilou-se durante o governo de Juan Manuel de Rosas $^{5}$. Na capital uruguaia, frequentava espaços de sociabilidade acompanhada de seu pai, teve sua primeira experiência docente ao abrir um Ateneo de Señoritas com a mãe, publicava poemas e outros tipos textuais em periódicos liberais e aproximou-se de intelectuais da Geração de 1837, com quem passou a estabelecer uma relação letrada ${ }^{6}$.

\footnotetext{
${ }^{5}$ Manso nasceu em Buenos Aires em 1819. Seu pai era um engenheiro andaluz, José María Manso, e sua mãe, uma portenha chamada Teodora Cuenca. Sabe-se que, incentivada por ambos, que eram liberais, ela frequentou a primeira Escuela Normal criada por Bernardino Rivadavia no período da "feliz experiência" argentina. Ela tinha apenas 17 anos quando a família se retirou para Montevidéu; no início da década de 1840, o exílio continuou na capital do Império brasileiro juventude (LEWKOWICZ, 2000).

${ }^{6}$ Juana Paula Manso não só se correspondeu com sujeitos como José Marmol, José María Gutiérrez e Domingo F. Sarmiento, mas seu romance "Misterios del Plata" guarda relações com a estética e a visão de mundo que eram próprias dos jovens da Geração de 1837 (GRAU-LLEVERIA, 2010, p. 6). Ela, no entanto, não costuma ser sequer mencionada como parte daquele grupo de intelectuais, o que pode ser pensado não só como um apagamento da personagem e de seus escritos do cânone literário e da historiografia que aborda o período, mas uma exclusão realizada pelos próprios "letrados românticos". Liliana Zuccotti ressaltou isso em um dos seus textos em que abordou a trajetória de Manso: "Su edad, su experiencia de un largo exilio, la sitúan, sin duda, junto a la 'joven generación' del 37. Pero si el estudio, la confraternidad con los jóvenes escritores, el ensayo de una escritura poética, el uso de la prensa, el trabajo como maestra, colocan a Juana Manso como una supuesta interlocutora 'ideal' para los escritores de esta generación, es sobre su figura donde mejor podrán leerse los límites de la prédica liberal en 'la cuestión de las mujeres'. [...] no habrá figuras femeninas - ni aún secundarias - en el perfil del grupo" (1998, p. 378).
} 
Residindo no Brasil, Manso se casou com um músico português, Francisco de Sá Noronha, viajou com ele para os Estados Unidos e para Cuba (produzindo relatos sobre suas experiências e observações de viajante), teve duas filhas chamadas Hermínia e Eulália, abriu um colégio para meninas, escreveu e atuou em peças de teatro, compôs zarzuelas e fundou seu próprio jornal intitulado "Jornal das Senhoras. Modas, Litteratura, Bellas-Artes, Theatro e Crítica". O "Jornal das Senhoras" foi uma das primeiras publicações periódicas dirigida por e para mulheres no nosso país ${ }^{7}$ e começou a circular em janeiro de 1852. Nele, Manso publicou o romance folhetim "Misterio del Plata. Romance Histórico Contemporaneo" e uma série de textos em que refletia sobre a necessidade da educação e da emancipação femininas, começando a sua trajetória como uma "intelectual feminista transnacional", categoria criada por Barbara Souto (2019) ao estudar o trabalho da letrada naquele período. Apesar de ter sido impresso até 1855, Juana Manso somente editou e redigiu o jornal em seu primeiro semestre de existência. Ela retornou a Buenos Aires em 1853, após o fím do governo de Rosas e quase duas décadas distante de sua cidade natal, tendo já perdido seus pais, com o casamento desfeito e com as filhas pequenas.

Apenas chegada em Buenos Aires, Manso teria começado a procurar emprego em jornais de tendência liberal, sem êxito. No entanto, a letrada não foi recebida pela sociedade bonaerense com entusiasmo e ainda teve que enfrentar um ambiente que lhe foi "abiertamente desfavorable" (AREA, 2005, p. 11). Não encontrando um espaço desde o qual pudesse escrever publicamente em Buenos Aires e apesar do "escaso dinero que aún poseía" (AREA, 2005, p. 11), ela acabou por retomar seu trabalho jornalístico e intelectual iniciado no Rio de Janeiro, fundando um novo semanário logo

\footnotetext{
${ }^{7}$ Apesar de o periódico iniciado por Manso ser comumente lembrado e referenciado como o fundador do periodismo feminino no Brasil, Zahidé Lupinacci Muzart esclarece que Maria Josefa Barreto já havia fundado em 1833, em Porto Alegre, o jornal "Belona Irada contra os Sectários de Momo", mais conhecido como "Belona". Entretanto, ainda segundo a estudiosa, "o Belona não fez escola, e o que se tornou modelo inicial para os periódicos feministas do século XIX foi o Jornal das Senhoras" (MUZART, 2013, p. 229).
} 
no primeiro dia de 1854. O "Album de Señoritas. Literatura, Modas, Belas Artes y Teatros" foi o primeiro impresso argentino cuja propriedade, direção e autoria dos textos publicados haviam sido nominalmente assumidos por uma mulher. A intelectual inauguraria no Rio da Prata, assim, aquilo que Graciela Batticuore definiu como uma "autoría apropriada y exhibida" (2005, p. 132). Além disso, a letrada voltava a demarcar a sua posição e a difundir suas ideias, agora na Argentina, sobre a importância da educação popular, especialmente a de meninas, como forma de promover a sua emancipação: “Todos mis esfuerzos serán consagrados á la ilustracion de mis compatriotas, y tenderán á un único propósito - Emanciparlas de la las preocupaciones torpes y añejas que les prohibian hasta hoy hacer uso de la inteligencia, enagenando su libertad y hasta su conciencia" (ALBUM, n. 1, 01 jan. 1854, p. 1), ela escreveu nas páginas iniciais do primeiro número do impresso.

As temáticas publicizadas, a linguagem politizada e o compromisso incontornável com a defesa de causas sociais de Juana Manso ${ }^{8}$ eram elementos inusitados para a sociedade bonaerense da época, já que, conforme Graciela Batticuore, naquele momento, as outras escritoras, ainda que produzissem sobre dramas nacionais, não chegavam a construir seus discursos em um tom tão realista ou com uma perspectiva política tão explícita (2015, p. 152-153). O resultado foi que o "Album de Señoritas" teve seu fim apenas oito semanas após o primeiro número ter ido a público. Ocorre que Juana Manso dependia das assinaturas e do apoio financeiro de suas leitoras para manter o semanário existindo e para continuar atuando nesta "suerte de tribuna pública" (BATTICUORE, 2005, p. 132) que havia criado para si, pois não contava com nenhum amparo institucional ou publicidade comercial. Já no quinto número da

\footnotetext{
${ }^{8}$ No "Album de Señoritas", Manso pretendia aprimorar a "bagagem intelectual das leitoras, que poderia culminar em reflexões mais refinadas e críticas sobre a própria condição das mulheres oitocentistas" (SOUTO, 2019, p. 95). Por isso, além de escrever sobre a educação e a situação femininas, falava de ciência e filosofia, da chegada de inovações tecnológicas no continente e do desejado "progresso" argentino, ao tempo em que criticava as sociedades escravistas, a violência estatal cometida contra populações nativas, a Igreja Católica e sua influência na sociedade portenha. Sobre isso, ver SOUTO, 2019.
} 
publicação, a intelectual suplicava à sociedade de Buenos Aires que suportasse o jornal prestes a fenecer, ressaltando as condições materiais que tinha e os esforços que desprendia para que suas ideias circulassem (ALBUM, n. 5, 29 jan 1854, p. 40). Para Lelia Area, o "fracasso" que ela sofreu implicava "(de)mostrarle [...] la inutilidad de su palabra inteligente, sino que, al mismo tiempo, ubicaba a la mujer en la precariedady desamparo económicos al condenarla a un trabajo sin retribución” (2005, p. 46). Não à toa, no mesmo número em que indicava que seu jornal corria risco de se acabar, Manso divulgava um anúncio em que informava: "Para el próximo mes de Febrero, la redactora del Album ofrece dar lecciones de los idiomas inglés, francés e italiano, en casas particulares" (ALBUM, n. 5, 29 jan. 1854, p. 40). Para garantir uma renda e exercer um ofício mais bem aceito pela sociedade oitocentista às mulheres do que o de escritora e publicista, ela tentava voltar a exercer o papel de preceptora, como já havia sido em Montevideu e no Rio de Janeiro nas décadas de 1830 e 1840.

Os primeiros anos pós-Caseros foram tempos ainda bastante difíceis na conjuntura argentina. Apesar do fim do rosismo, o processo de rearticulação dos campos político, institucional e letrado foi conflitivo; a reorganização da Confederação Argentina se dava sob a liderança do entrerriano Justo José de Urquiza e um grupo heterogêneo que não contava com a hegemonia bonaerense. O retorno das emigradas e dos emigrados "renovó los círculos en que se movian las elites en la capital" (SABATO, 2012, p. 325). As tramas de relações sociais e políticas se recompunham ${ }^{9}$ e, enquanto o poder central procurava se estabelecer a partir do Litoral com o acordo de San Nicolás, a Província de Buenos Aires, sob a liderança ascendente de Mitre e dos liberais portenhos, se manteve como estado separado da Confederação. É possível que o cenário de instabilidade e de conflito que perdurou naquele espaço até fins da década de 1850 ,

\footnotetext{
${ }^{9}$ Os debates e processos de reconfiguração das elites políticas e letradas argentinas no período que se seguiu à derrota de Rosas podem ser exemplificados na produção de diagnósticos e projetos distintos para a nação realizados por Juan Bautista Alberdi e Domingos Faustino Sarmiento. Sobre este contexto, ver os primeiros capítulos de: BONAUDO, Marta (dir.). Nueva Historia Argentina. Volúmen 4: Liberalismo, estado y orden burgués (1852-1880). Buenos Aires: Editorial Sudamericana, 1999.
} 
além do insucesso de sua primeira experiência jornalística por ali, tenham sido fatores que contribuíram para que Manso não tenha conseguido se estabelecer efetivamente em seu país naquela ocasião. Ela acabou por retornar ao Brasil, em uma nova passagem pelo Rio de Janeiro, que durou quatro anos ${ }^{10}$. Em 1859, no entanto, a intelectual estava de volta a Buenos Aires, onde iniciou os ofícios de maestra e principal da primeira escola primária pública e mista estabelecida na Província por Domingo F. Sarmiento, então diretor do Departamento de Educação.

É deste momento em diante que Manso se aproximou definitivamente do autor de "Facundo", com quem estabeleceu uma relação intelectual e de amizade bastante próxima (PEARD, 2008), como é possível perceber no início deste artigo. A produção de textos em vários gêneros, a criação e a comunicação de ideias não deixavam de ser preocupações e desejos dela. Assim, além de exercer o magistério, ela continuará promovendo tentativas de escrita e publicação em Buenos Aires durante a década de 1860, apesar da rejeição e da frustração que havia sofrido na cidade no decênio anterior. Agora, no entanto, o contexto se alterava: os liberais portenhos com quem Juana Manso dialogava haviam imposto a sua influência sobre o resto do país e a unificação definitiva da República Argentina passava a realizar-se sob o domínio de Buenos Aires. A afinidade com as ideias e convicções deste grupo, especialmente com as de Sarmiento, além de sua atuação docente em instituições estatais de ensino, autorizou a intelectual a tornar-se redatora e diretora, em 1865, dos “Anales de la Educación Común". Tratava-se de uma publicação oficial destinada ao público geral, editada pelo governo provincial e patrocinada pelo nacional, a partir da qual "procuróse promover la causa de la educación primaria pública" (SABATO, 2012, p. 181). Os “Anales"

\footnotetext{
${ }^{10}$ Há poucas investigações que esclareçam exatamente quando e como se deu o retorno de Juana Manso ao Brasil e que revelem como foi sua segunda estadia no Rio de Janeiro, entre meados e fins da década de 1850. Durante esta pesquisa, encontrei, em jornais cariocas, algumas indicações de que entre 1855 e 1858, ela atuou como autora e atriz de peças de teatro - ela já havia colocado em cena dramas de sua autoria em sua primeira passagem pela capital do Império brasileiro - e publicou alguns textos autorais em periódicos.
} 
tornaram-se a principal plataforma a partir da qual ela produziu, refletiu e debateu as pautas educacionais e pedagógicas nacionais (PEARD, 2008, p. 463). Neles, ela publicava não só documentos e textos que abordavam a trajetória recente do ensino público na Argentina, mas também escritos próprios sobre a temática e traduções que fazia de produções de educadores estrangeiros, como as dos educadores norte-americanos - e seus correspondentes - Horace e Mary Mann. Neste periódico, assim, Manso defendeu a educação popular, laica e igualitária para meninos e meninas de diferentes classes sociais e de distintos espaços geográficos da Argentina; também acabou por registrar e estabelecer as suas próprias versões dos ataques e embates que lhe ocorreram, como demonstrarei adiante neste artigo.

Sua proximidade com os liberais de Buenos Aires, permitiu-a, também, produzir e publicar o "Compendio de la Historia de las Provincias Unidas del Río de la Plata", manual didático de história que foi oficialmente adotado nas escolas argentinas e, assim, adquirido com recursos estatais a partir de 1862, ano em que Bartolomé Mitre se tornou presidente da república. Nas páginas iniciais da primeira edição do livro, Manso incluiu um texto dedicado ao governante-historiador intitulado "Homenage de gratitud", em que afirmava:

\begin{abstract}
Me han servido de texto el Ensayo Histórico del Dean Funes, y la
Biografía de Belgrano escrita por V.; obra que el mismo Sr. Sarmiento remitió al Archivo de esta Escuela para que me iluminase en mi arriesgada empresa. Por modesto que sea este libro, él está destinado á llenar un grande vacío que se siente en los libros de enseñanza, y es esa la única esperanza que me anima al someterlo al elevado juicio de V., y pedirle la adopción en nuestras Escuelas si lo considera digno de llenar tan alta mision (MANSO, 1862, n.p.)
\end{abstract}

Logo depois da dedicatória, o manual trazia uma carta escrita pelo próprio Mitre em abril daquele ano e dirigida à intelectual, em que ele lhe dizia o seguinte:

Señora mía y amiga. Devuelvo á V. los cuadernos relativos á la historia del Rio de la Plata, que ha tenido la bondad de comunicarme, honrándome con su dedicatoria. Dispense V. que los haya detenido tanto tiempo; pero deseaba leerlos con detención, y este ha sido el motivo. Hoy al devolvérselos, puedo decirle que es una obra cuya necesidad se hacía sentir, y que lo considero muy adecuado para servir de libro elemental de historia en las escuelas 
primarias, siendo su plan sencillo, habiendo método en la esposicion de los hechos, y bastante exactitud, á lo que se agrega un estilo correcto. (MANSO, 1862, n.p.)

Pode-se compreender a presença desses elementos na introdução da obra como uma estratégia construída por Juana Manso para conseguir publicar o trabalho e defender a sua relevância. Em primeiro lugar, é preciso considerar que o "Compendio" de Manso foi um dos primeiros manuais escolares de história produzidos em Argentina ${ }^{11}$. A autora tomava a frente de ocupar o "grande vazio" que ela mesma identificava na produção historiográfica do país: a ausência de obras sobre o passado da nação escritas dirigidas ao ensino e à aprendizagem de crianças - e de mulheres - sobre o tema e que tivessem, para isso, um certo cuidado em sua apresentação escrita, que, para ela, deveria ser realizada com "simplicidade", ou mesmo em versos ${ }^{12}$. Não sem razão, a originalidade e a urgência de sua iniciativa são destacadas tanto na dedicatória que Manso fez a Mitre quanto na carta que ele a escreveu. A história argentina, afinal, havia sido incluída como matéria nos currículos escolares - sendo separada da história geral justamente no início da década de 1860, no marco do início da presidência de Mitre e da produção de projetos historiográficos e institucionais que buscavam construir relatos fundadores da nação, conformar uma memória coletiva e que tentavam consolidar o Estado Nacional (FRANCO, 2003; POGGI, 2013).

No mesmo material, Juana Manso fez questão de evidenciar quais foram as obras que leu para produzir sua escrita da história. Além do "Ensayo de Historia Civil del Paraguay, Buenos Aires y Tucumán” do Deán Gregorio Funes” (1816), ela também utilizou como referência a "Biografia del General Belgrano" (1857), de autoria do

\footnotetext{
${ }^{11}$ Como se verá a seguir, Luis Domíngues editou um manual chamado "Historia argentina” em 1861, ou seja, um ano antes da publicação do "Compendio" de Manso.

${ }^{12}$ No "Album de Señoritas" Juana Manso alertava sobre a necessidade de suas compatriotas conhecerem "los antecedentes de la historia propia, porque si es disculpable no conocerse [...] la historia de las diferentes naciones que pueblan la tierra, es absurdo vergonzoso no conocer la situación de su propio país y su historia (ALBUM, n. 6, 05 fev. 1841, p. 42). Para isso, ela indicava a necessidade de organizar "la historia del descubrimiento, conquista, revoluciones, geografía, productos \&a. \&a. del Río de la Plata, pero escrita con sencillez, y si posible fuese en verso" (ALBUM, n. 6, 05 fev. 1841, p. 42).
} 
próprio Bartolomé Mitre, a qual acessou por trabalhar na Escuela Normal Mixta $N^{o}$, para cujo acervo Sarmiento a enviou ${ }^{13}$. É digno de atenção, ainda, o fato de a letrada reproduzir as palavras que o presidente-historiador escreveu aprovando o manual, inclusive no que se refere ao seu método, à sua correção e ao seu estilo. Sendo o "Compendio" uma obra sobre o passado nacional escrita por uma mulher, é provável que houvesse uma necessidade refletida de justificar a sua publicação (inclusive por se tratar de um manual oficial, que circularia com apoio do governo) e, mais que tudo, de validar e conferir autoridade à produção. Manso procurou demonstrar o fato de (re)conhecer o trabalho de outros historiadores, incluindo-se no debate historiográfico produzido no espaço platino, e manifestar publicamente que tinha o respaldo de Mitre para escrever história ${ }^{14}$. Ao mesmo tempo, afirmou que seu livro era "modesto", tópica usual entre autoras que escreviam sobre temas que não eram considerados relacionados à racionalidade feminina, como o estudo do passado, para proteger-se de possíveis críticas e silenciamentos quanto à sua “ousadia” (OLIVEIRA, 2018, p. 129). Como argumenta Stella Maris Scatena Franco, afinal, o "uso de uma retórica auto desqualificadora era, em geral, mobilizada estrategicamente [pelas escritoras] com o objetivo de preservar a imagem de que agiam consonante com as regras de respeitabilidade voltadas às mulheres [...]" (2018, p. 229).

Ainda assim, o "Compendio de la Historia de las Provincias Unidas del Río de la Plata" sofreu fortes objeções dentro do próprio Departamento de Escuelas,

\footnotetext{
${ }^{13} \mathrm{Em}$ um contexto em que os rendimentos da intelectual, pode-se supor, não eram suficientes para formar uma biblioteca pessoal de fôlego e em que o acesso aos repositórios públicos de livros e documentos era restritivo às mulheres, estabelecer relações com homens de letras (estes, sim, com ampla possibilidade de compra e consulta de bibliografia) se tornava ação imprescindível para alcançar obras e materiais de referência. Sem dúvida, trabalhar em uma escola, ainda que primária, também ajudava Manso neste sentido.

${ }^{14}$ Ressalto, neste sentido, que naquele momento, além de ser presidente da república e autor da "Biografia del General Belgrano", Mitre já havia escrito "Galería de celebridades argentinas" (1857) e a "Historia de Belgrano" (1859). Também detinha boa parte da documentação sobre a história argentina em seu arquivo pessoal e havia fundado o Instituto Histórico e Geográfico do Rio da Prata (1854), em uma tentativa de institucionalizar a prática histórica na Argentina. Nas décadas seguintes, ele protagonizou os principais debates sobre como se deveria escrever a história da nação, como se verá adiante.
} 
especialmente por parte do então diretor do órgão, Juan María Gutiérrez ${ }^{15}$. É o que ela mesma conta em uma carta remitida a Sarmiento logo após o livro ter sido publicado:

Publiqué al fin mi Compendio; en el Departamento dejé un ejemplar para V. con estas palabras: Al Sr. Sarmiento: recuerdo de una amiga. Le remito otro ejemplar por que tal vez allí se hayan olvidado de enviárselo. La publicación del Compendio, me ha conquistado el odio del Sr. Inspector, y el departamento se halla en serios embarazos para dictaminar en el expediente de adopción; esto, a pesar de la carta del General Mitre, y de haberse subscrito el gobierno por quinientos ejemplares. El departamento es algo difícil; no sabían que remontar un río es navegar contra la corriente; y a pesar de invocar yo en mi abono el Diccionario de la Academia, el Inspector dice que remontar es cosa de barriletes! En "foncée" la Academia! En favor del libro, opina Luis Domingues y otras personas incapaces de defraudar el trabajo ajeno; lo que no obsta a que yo esté hoy "entre a cruz e a caldeirinha" como dicen los portugueses: he prevenido al Sr. Gefe Interino que a otra visita de desagrado del Sr. Inspector, elevo mi renuncia [...]. (MANSO apud VELASCO Y ARIAS, 1937, p. 315)

A partir desta correspondência, é possível perceber que a obra de história de Juana Paula Manso correu sério risco de não ter sido adotada como material didático nas escolas argentinas. Mesmo com as estratégias construídas por ela para que seu texto fosse bem recebido, após alguns exemplares já terem sido comprados pelo governo e apesar de opiniões favoráveis ao livro - como a de Luis Dominguez, sobre quem falarei adiante -, Gutiérrez colocava a intelectual "entre a cruz e a caldeirinha", como ela mesma disse, fazendo-a inclusive considerar a renúncia de seu cargo estatal. Em seu relato, Manso indicava que a publicação do "Compendio" fez com que o diretor do Departamento tivesse "ódio" dela. Além disso, contava que teve até mesmo que

\footnotetext{
${ }^{15}$ Nos embates de reconfiguração dos campos político e intelectual ocorridos após o fim do governo de Rosas, Juan María Gutiérrez havia se posicionado em defesa do acordo de San Nicolás, tornando-se, inclusive, integrante do governo de Urquiza. Isso situou o letrado em oposição aos liberais portenhos e o fez experienciar "uma atmosfera árida e de permanência impraticável na vida político-intelectual da província de Buenos Aires" na década de 1850 (TERLIZZI, 2019, p. 71). Ainda segundo Bruno Passos Terlizzi, foi seu capital intelectual simbólico que lhe permitiu reinserir-se no cenário acadêmico-educacional no governo de Mitre. Apesar dessa reinserção, penso que é possível considerar que as "clivagens que os letrados argentinos integrantes da Geração de 1837 passaram a enfrentar em 1852" (2019, p. 69) possam ter, de alguma forma, influenciado nas críticas que Gutiérrez teceu sobre o "Compendio" de Juana Manso.
} 
comprovar a ele a correção de uma determinada palavra que havia usado em seu escrito, mostrando-lhe, em sua defesa, o significado do verbete no "Dicionário da Academia".

Um documento redigido por Juan María Gutiérrez no primeiro dia de dezembro de 1862 torna evidente o que ele pensava sobre este trabalho de Manso - e corrobora com a narrativa dela, que apresentamos acima, de que o diretor havia colocado em dúvida a qualidade da obra e ameaçava a sua circulação. Trata-se de um parecer que ele produziu (e provavelmente enviou) para um integrante do governo ${ }^{16}$ no qual justamente recomendava, contrariando a posição de Bartolomé Mitre e de Dominguez, que o “Compendio" não fosse adotado como livro oficial de ensino e, para isso, adquirido com dinheiro público. Já na introdução de seu texto, Gutiérrez ajuizava que isso não deveria ser resolvido conforme as razões expostas pela autora, nem pelas que foram alegadas pelo Departamento de Escuelas, pois "la protección y estímulo a favor de los profesores que se dedican a las letras [...] son de resorte del público" e os governos, "si éstos hubiesen de contribuir en algo a aquellos fines", deveriam fazê-lo em "muy estricta consonancia con el [...] valor del escrito ya comprende p. el lado de las ideas ya p. el la ([s]) de su forma y estilo" (MOGLIA; GARCÍA, 1990, p. 159). O letrado, então, descreveu o que ele considerava como um manual didático de história valoroso em termos de ideias, forma e estilo e que, por isso, seria digno de "proteção e estímulo" governamentais:

Obras escritas con este ([propósito]) objeto deben contener ([la verdad...]) en dimensiones reducidas la verdad más necesaria del ramo de conocimientos a q. se contraigan. El estilo debe ser llano, culto, sin afectación; el lenguaje correcto y propio y en cada pájina y palabra debe respirar un alto sentido moral, condiciones todas que no puede satisfacer sino los escritores ([de

\footnotetext{
${ }^{16}$ Escrevi "provavelmente enviou" pelo fato de que tive acesso somente a um rascunho de tal documento produzido por Juan María Gutiérrez, guardado pelo próprio intelectual em seu arquivo pessoal e publicado em seu epistolário editado em 1990 pela Biblioteca del Congreso de la Nación. Não há como afirmar para quem exatamente o informe do letrado era dirigido (essa informação está omitida), se foi de fato enviado ao governo depois de "passado a limpo" ou se (ou como) repercutiu institucionalmente. Por se tratar de um esboço, o escrito tem algumas interpolações realizadas por Gutiérrez, que aparecem entre parênteses e colchetes e demonstram que o autor ainda se decidia sobre quais termos utilizaria em sua redação final. Nas citações de trechos do documento que acompanham minha análise a seguir, transcrevi-o tal como ele foi impresso na edição consultada.
} 
gusto para]) q. hayan hecho estudios serios y ([hayan]) tengan acrisolado el gusto en la frecuencia ([de excelente]) y meditación de excelentes modelos. (MOGLIA; GARCÍA, 1990, p. 159)

Depois de salientar que esperava que um livro deste tipo deveria conter "a verdade mais necessária" do campo de conhecimento ao qual se relaciona, ter estilo "culto e sem afetação", "linguagem correta e própria", além de ser produzido por escritores (ressalto a flexão de gênero utilizada aqui) que tenham feito "estudos sérios" e "refinado o gosto" a partir da leitura recorrente e da meditação de "excelentes modelos", Juan María Gutiérrez passava às suas considerações sobre o "Compendio" de Juana Paula Manso:

Contrayéndome al libro titulado Compendio de la Historia de las Prov. Unid. del R. de la P., escrito por la respetable preceptora Da. J. P. de N. debo ([decir record.] comenzar por recordar a V.E. que él aparece mucho después que circula entre nosotros y que se ha aceptado como texto de lectura en las Escuelas la Hist. argentina [(en las obras que)] que abraza la vida toda de nuestro ([del]) pueblo ([argentino desde]) hasta fines de 1819; ([libro]) Hist. sea dicho de paso que para nada menciona la Sa. de Noronha en su dedicatoria de su obra ([al autor de la Vida de Belgrano)]. Sin embargo mi persuasión es q. si el libro del Sr. Domínguez no hubiera visto la luz estaría todavía en las tinieblas el que motiva este informe [...]. (MOGLIA; GARCÍA, 1990, p. 159)

Nas primeiras linhas da apreciação crítica da obra, Gutiérrez desfazia o argumento sobre a originalidade e necessidade da obra, argumentando que o livro de Manso aparecia "muito depois" que a "Historia Argentina" de Luis Dominguez tenha começado a circular. O intelectual criticava a autora, ainda, por não ter citado aquela obra entre suas referências apresentadas na dedicatória a Mitre, procurando indicar que ela não estava exatamente em sintonia com as produções historiográficas e as discussões dos círculos letrados portenhos, ou feito a leitura de "excelentes modelos", para usar as palavras do próprio parecerista. É preciso ressaltar, no entanto, que o manual de história de Dominguez havia sido lançado somente um ano antes, em 1861. Se pensarmos que a carta do presidente-historiador para Juana Manso elogiando o “Compendio" é datada de abril de 1862 e que, portanto, naquele momento, o livro dela 
já havia sido não só finalizado, como enviado e lido por outras pessoas, é possível considerar que as duas obras - a de Dominguez e a de Manso - foram produzidas quase simultaneamente. Neste sentido, parece que, aqui, Gutiérrez foi descomedido em seu arrazoado. Mas ele ainda foi além ao afirmar que mesmo que a "História Argentina" não tivesse "visto a luz" antes, ainda assim o "Compendio" estaria nas "sombras" ou na “escuridão". Ou seja: para ele, mesmo se o manual de história de Manso fosse o único existente na Argentina, não poderia ser utilizado por docentes ou estudantes por não ser qualificado o suficiente para isso.

A partir de então, Juan María Gutiérrez passava a pontuar no seu parecer alguns (outros) problemas que via na obra histórica da intelectual e que justificariam que ela fosse situada "en las tinieblas" da bibliografia e da historiografia do país. Segundo o letrado, em sua narrativa, Manso não explicitava em qual data exatamente teriam ocorrido alguns eventos importantes do passado nacional, como o "descubrimiento del Nuevo Mundo", o início da "expedición de Solís al R. de la Plata" ou quando "se fundó Bs. As. por primera vez". Para ele, isso não era "adecuado a la inteligencia juvenil ([a]) la cual ([es pred.]) está vacía de hechos y de datos, ambiciona por llenarse de ellos [...]” (MOGLIA; GARCÍA, 1990, p. 160). Gutiérrez também criticava o fato de o “Compendio" não mencionar alguns dos nomes dados por conquistadores espanhóis a certos lugares durante o processo de exploração da região platina, o que poderia causar alguma confusão quanto à compreensão de "geografía comparada del país" pelas crianças (MOGLIA; GARCÍA, 1990, p. 160). Após escrever que considerava imprópria uma determinada expressão utilizada por Juana Manso para narrar uma ação de indígenas Querandies ainda nos primeiros anos de contato entre eles e os europeus, o intelectual dizia que não mais listaria possíveis "erros" da autora, dizendo o seguinte: “Me parece escusado pasar [(a)] más adelante de las 5 pájinas primeras de hist. antigua q. acabo de leer y examinar por encima"(MOGLIA; GARCÍA, 1990, p. 161). 
Ainda no parecer que fazia ao governo de uma obra cuja leitura dizia, de forma arrogante, ter lido "por cima" - dando a entender que se tivesse analisado de forma aprofundada, teria encontrado mais pontos negativos a indicar -, Gutiérrez afirmava que a própria escrita produzida por Manso era “infructuosa p. los niños si no fuese perjudicial por el estilo un tanto periodístico ([con que]) que [(brilla)] relumbra en casi todas sus páginas" (MOGLIA; GARCÍA, 1990, p. 161). Depois, ele retomava sua recomendação para que o "Compendio" não fosse oficialmente aceito como livro didático nas escolas públicas argentinas, acrescentando que devido ao "creciente progreso intelectual" da Argentina, ele "bien pronto sería reemplazado por otro u otros más adequados a su objeto" (MOGLIA; GARCÍA, 1990, p. 161). Ao terminar seu escrito, o diretor do Departamento de Escuelas afirmava o seguinte: "Habría deseado también tener motivo para ([elogiar]) aplaudir y no para censurar el desempeño del Compendio porque no pueden menos que interesar el esfuerzo de una señora para ser útil a la juventud con los con los frutos de su inteligencia y con su aplicación" (MOGLIA; GARCÍA, 1990, p. 161).

Não se pretende, neste texto, analisar o conteúdo ou o estilo narrativo do “Compendio", nem cotejá-lo com os comentários críticos realizados por Juan María Gutiérrez. O objetivo aqui, afinal, é demonstrar os esforços empreendidos para silenciar Juana Paula Manso enquanto ela tentava inserir-se na arena pública como uma intelectual. A situação descrita nos parágrafos acima é mais um exemplo de como foi difícil para ela adentrar ao círculo letrado bonaerense oitocentista, especialmente quando tratava de temas que eram convencionalmente tidos como mais apropriados aos homens. Ao apontar o que Manso deveria ter lido, ao se incomodar de maneira tão contundente com as escolhas metodológico-didáticas e narrativas que ela realizou, bem como ao classificar o trabalho dela no "Compendio" como um mero (e já expirado) “esforço de uma senhora para ser útil à juventude", Gutiérrez tentava exclui-la do grupo de quem considerava que poderia escrever e publicar sobre história na Argentina. Havia, 
afinal, um limite quanto aos campos de saber que uma mulher letrada como a nossa personagem poderia acessar efetivamente: no século XIX, ser uma historiadora e produzir reflexões sobre o passado era ainda mais desafiador do que ser "apenas" uma escritora pública. Esse desafio ia além da impossibilidade de as mulheres acessarem os espaços de educação formal ou aqueles nos quais a documentação e as obras eram guardadas, como as bibliotecas e os arquivos públicos e privados. À medida em que a História ia se conformando como uma disciplina ao longo do oitocentos, ela ia sendo também controlada por homens que detinham um determinado "saber fazer" - criado por eles mesmos - que envolvia normas, métodos, formas de escrita, processos de institucionalização ${ }^{17}$. O processo de estandardização deste "saber fazer" masculino, não incluía - pelo contrário - as maneiras como muitas letradas se aproximavam do conhecimento histórico naquele momento. Conforme Angelika Epple (2013), elas não usavam uma metodologia específica, nem se relacionavam com os requerimentos da emergente disciplina; assim, suas narrativas acabavam não sendo consideradas como apropriadas ao gênero "história". No entanto, tanto a historiadora alemã quanto outras estudiosas do campo ${ }^{18}$ têm procurado afirmar que mesmo afastadas dos cânones ou sendo concebidas em seu tempo (pelos outros ou até por elas mesmas) como “incapazes" ou "más profissionais" (SMITH, 2003, p. 17), as mulheres escreveram história e produziram interpretações de eventos e personagens do passado no XIX, devendo ganhar a atenção dos estudos de história da historiografia. A escrita da história elaborada por elas naquele período correspondia, em grande medida, ao que chamamos hoje de "historiografia popular" (EPPLE, 2013). Elas produziram biografias, manuais

\footnotetext{
${ }^{17} \mathrm{Na}$ Argentina, por exemplo, o momento que a história da historiografia costuma identificar como aquele em que se organiza o campo historiográfico argentino foi protagonizado por dois homens: Bartolomé Mitre e Vicente Fidel López. Os dois promoveram, entre 1881 e 1882, um debate que teria orientado outros letrados (também homens, que participavam de discussões públicas como essas e dos círculos ilustrados) sobre quais seriam os sentidos, as formas e o papel da escrita da história na construção da nação (MENDIETA, 2018).

${ }^{18}$ Como Bonnie G. Smith (2003) e, mais recentemente, as brasileiras Flávia Florentino Varella (2020) e Jeane Carla Oliveira de Melo (2020).
} 
didáticos de história, obras voltadas ao público infantil, relatos de viagem, romances, poemas e teatros históricos, dentre vários outros tipos narrativos que continham reflexões sobre o pretérito - inclusive, como no caso do "Compendio" de Manso, sobre os passados nacionais.

Cabe ressaltar que Juana Paula Manso não se furtou de escrever sobre o passado da Argentina, mesmo depois dos comentários desabonadores de Juan María Gutiérrez sobre o seu trabalho no "Compendio" e da tentativa de invalidar o livro como adequado ao uso nas salas de aula para o ensino de História. O próprio manual não só foi publicado em 1862, como já mencionado, como foi por ela editado sucessivas vezes até a década seguinte ${ }^{19}$. Em 1864, Manso escreveu e lançou no mercado editorial o teatro "La Revolución de Mayo de 1810", no qual selecionou os acontecimentos tidos como heroicos da emancipação da Argentina diante da Coroa Espanhola e os narrou sob a forma de um "drama histórico", como a obra foi descrita na capa editada pela Imprenta de Mayo. No mesmo ano, a intelectual ainda iniciou a produção e a publicação de biografias em séries de textos intituladas "Mujeres Ilustres de la América del Sur" e "Mujeres Ilustres de la República Argentina". Com estes escritos, ela pretendia apresentar para as suas leitoras as trajetórias de mulheres que atuaram no continente americano e no território rio-platense desde o período das guerras de Independência ${ }^{20}$. "Mujeres Ilustres" acabou sendo, no entanto, um trabalho inconcluso: os dois jornais

\footnotetext{
${ }^{19}$ As edições posteriores à inaugural que pude consultar trazem a seguinte informação em suas folhas de rosto: "Este libro ha sido aprobado por el Consejo de Profesores del Colegio Nacional de Buenos Aires en 1863 y por el Consejo de Instrucción Pública de esta misma Provincia en 1869". Para se ter ideia, a sexta edição da obra foi lançada pela Tipografia del Diário La Época em 1875, apenas um ano após o falecimento de Manso. No ínterim entre a primeira impressão do "Compendio" e 1874, a intelectual continuou trabalhando na obra, alterando diversos pontos de sua escrita, ampliado o seu recorte temporal (chegando a abordar acontecimentos das décadas de 1860 e 1870) e até mesmo repensado a forma de apresentação da narrativa, motivada por escolhas didáticas e, talvez, pelas críticas que recebera em 1862.

${ }^{20}$ Ressalto que em 1857, Bartolomé Mitre havia publicado uma obra chamada "Galería de celebridades argentinas: biografias de los personajes más notables del Río de la Plata”, na qual narrava as histórias de vida de personagens do passado argentino; como se pode imaginar, no entanto, no livro produzido por ele somente há biografias de homens.
} 
nos quais as biografias começaram a ser publicizadas, "La Flor del Aire" e "La Siempre-Viva", tiveram o mesmo destino que o "Álbum de Señoritas" uma década antes.

"La Flor del Aire. Periódico literario ilustrado dedicado al bello sexo" foi um semanário editado por Luis Telmo Pintos, dirigido por Lope del Río ${ }^{21}$ e que teve como redatoras, além do próprio diretor, Juana Paula Manso e Eduarda Mansilla. Ambas publicavam seus escritos ali com os pseudônimos Dolores e Daniel, respectivamente, o que foi, possivelmente, uma estratégia editorial para protegê-las de críticas e ataques e permiti-las maior liberdade de expressão, em um ambiente social e cultural ainda hostil à atuação ativa de mulheres letradas. $\mathrm{O}$ primeiro número veio à público em 3 de março de 1864, já os derradeiros, entre abril e maio do mesmo $a^{22}$. O efêmero jornal "literário" conduzido por Pinto, Del Río e pelas duas escritoras argentinas tinha todo o conteúdo dirigido ao público feminino, como se pode perceber por seu subtítulo, tendo sido o primeiro a fazer isso em Buenos Aires desde que Manso encerrou as atividades do “Álbum” em 1854 (AUZA, 1988, p. 203). "La Flor del Aire" portava textos que giravam em torno de temáticas culturais e comportamentais que poderiam interessar e ilustrar as letradas portenhas, tais como as que eram anunciadas em todas as suas capas: “Literatura - Sátira decorosa - Teatro - Modas - Variedades". De fato, neste novo periódico, Juana Manso fazia um renovado esforço de adentrar a esfera pública bonaerense com um tipo de impresso a partir do qual a sua produção escrita e criativa pudesse ter maior regularidade, e suas ideias tivessem circulação mais ampla entre as mulheres - audiência que intencionava atingir e, principalmente, formar. Além disso,

\footnotetext{
${ }^{21}$ Segundo Néstor Tomás Auza (1988), Luis Telmo Pintos ficou conhecido, à época, por editar revistas literárias e femininas, como a posterior "La Ondina del Plata" (1875-1880). Já sobre Lope del Río, o mesmo autor afirma que há poucas informações que confirmem sua identidade e sequer é possível excluir que se tratasse de um pseudônimo.

${ }^{22}$ Auza (1988) supõe que o "La Flor del Aire" possa ter tido doze números, tendo existido até o fim de maio ou a primeira quinzena de junho de 1864 , pois, como veremos, ele foi continuado pelo semanário "La Siempre-Viva" a partir do dia 16 daquele mês. Não posso, no entanto, comprovar esta hipótese, já que somente consegui encontrar os cinco primeiros volumes em repositórios públicos argentinos (no Museo Mitre e na Biblioteca Nacional "Mariano Moreno"), sendo o último desta série consultada, o "La Flor del Aire" número 5, datado em 10 de abril de 1864.
} 
com sua atuação naquele semanário, ela almejava (mais uma vez) ser reconhecida como publicista, tanto pela sociedade em geral quanto pelo campo cultural argentino do período, bem como ser valorizada (e remunerada) como escritora profissional (VICENS, 2017). Ainda que não assinasse os textos com seu nome, Manso teve ativa colaboração em "La Flor del Aire" ao produzir artigos em que reafirmava o perfil e a aspiração autoral que já havia começado a traçar anteriormente no "Álbum de Señoritas". Neste sentido, María Vicens ressalta que os escritos da intelectual serão marcados "por la presencia de la primera persona y la biografía de la escritora, que asocian de manera intrínseca sus propuestas periodisticas con su figura" (VINCENS, 2017, p. 55).

Isso é potencializado quando o "La Flor del Aire" se torna "La Siempre-Viva", ainda em 1864. A mudança ocorreu em um movimento de refundação do semanário protagonizado por Juana Paula Manso ao assumir a direção de sua redação, como ela mesma anunciou na primeira edição, lançada em 16 de junho: "Al tomar a mi cargo la Redaccion de la Flor del Aire, creí que debia mudar nombre y formato al Periodico" (LA SIEMPRE-VIVA, n.1, 16 jun. 1864, p. 1). A intelectual passou, então, a trabalhar sozinha com o editor Luis Telmo Pintos, responsabilizando-se pela escrita dos materiais ali publicados. Mais do que isso, o pseudônimo "Dolores" foi abandonado por ela e seu verdadeiro nome (redigido "Juana Manzo") aparecia impresso logo no número inaugural, assinando o editorial acima citado em que comunicava as alterações que realizava. Em "La Siempre-Viva", Manso voltaria a editar textos em que intervinha de forma incisiva sobre a situação das mulheres argentinas para defender a sua emancipação. Fazia isso, no entanto, sem deixar de falar de questões como moda ou entretenimento, estas “pensadas como una dimensión 'inevitable' de la prensa de la época para captar a un público amplio" (VICENS, 2017, p. 52). Por essa razão, alertava: 
No vengo solo á contraerme á sostener el órgano de la Moda que es la cultura esterior; sino à crear un órgano de los intereses morales, é intelectuales de la mujer, que la instruya en su verdadero destino, la consuele en sus secretos pesares, y amenice sus tareas domésticas. Dios no ha creado las flores, solamente bellas; les ha dado aroma; no ha hecho la mujer únicamente hermosa, la ha dotado de un corazon blando, una organizacion sensible y una imaginacion ardiente. La ilustracion lejos de ser incompatible con la modestia, es el complemento de la belleza, porque es la perfeccion intelectual y moral de toda criatura. En nuestro pais, como por todas partes, el hombre cultiva su inteligencia, mientras que la mujer queda à retaguardia de la civilización." (LA SIEMPRE-VIVA, n.1, 16 jun. 1864, p. 1)

O subtítulo do projeto reinventado por Juana Manso passou a ser "Periódico literario ilustrado, dedicado al bello sexo argentino, escrito por señoras", assim mesmo, no plural. Ocorre que ela pretendia dividir as colunas de "La Siempre-Viva" com outras "senhoras" letradas que quisessem enviar seus escritos à redação, estimulando, assim, a formação e o aparecimento não só de leitoras, mas de novas autoras em Buenos Aires. O convite que Manso fez às suas compatriotas para que contribuíssem com assinaturas e com conteúdo ao impresso acaba sendo revelador das muitas barreiras que eram impostas às mulheres que, como ela, dedicavam-se (ou, pelo menos, pretendiam dedicar-se) à vida pública e intelectual na Argentina:

Ahí teneis el diario fundado que os ofrece sus paginas para os ensayes en el arte de vivificar la idea por la palabra transmitiendo el sentimiento al papel: habituemonos à la vida intelectual, un día ú otro la preocupacion que nos cierra las puertas de las Bibliotecas se quebrará, y el sentido comun demostrará que así como es libre la entrada de los Templos, de los Teatros, de los bailes y la concurrencia de los paseos, así nada tiene de subversivo á la moral que las señoras frecuenten las Bibliotecas, como sucede en todas partes del mundo civilizado. (LA SIEMPRE-VIVA, n.1, 16 jun. 1864, p. 2)

Antes que se "rompesse" efetivamente com a "preocupação" que negava a entrada das mulheres nas bibliotecas e nas instituições de saber, Juana Paula Manso decidia oferecer e abrir as páginas de seu jornal para que outras portenhas tirassem do mundo privado as suas palavras e transmitissem-nas ao papel para serem lidas por todas e todos. No entanto, as propostas da redatora não foram acolhidas: ela não conseguiu de 
suas leitoras nem o suporte financeiro, nem a parceria letrada de que necessitava para sustentar o "La Siempre-Viva". No que acabou por ser o último número do periódico, é possível ler o desapontamento de Manso com o silêncio que recebia como resposta daquelas que esperava que fossem suas interlocutoras e colaboradoras. Apesar de ainda manter-se vagamente esperançosa, a intelectual parecia sentir-se, além de desvalorizada e menosprezada, impossibilitada de continuar sua tarefa como jornalista e escritora, já que este era um fazer que realizava enquanto seguia dando aulas - afinal, seu emprego como professora em escolas públicas, provavelmente, era o que permitia que ela sustentasse a si e à sua família" ${ }^{23}$. Enquanto pedia outra vez por "cooperação material e intelectual", fazia questão de ressaltar que vivia de forma frugal, nas margens de Buenos Aires e sem tempo para distrações, pois se dedicava de forma integral às suas atividades profissionais e intelectuais ${ }^{24}$ :

No frecuento diversiones, no tengo amistades que me distraigan, vivo en una especie de ermitaga en un arrabal de la ciudad enseñando á leer las criaturas

\footnotetext{
${ }^{23}$ Lembro que naquele momento a intelectual ainda não era redatora dos "Anales de la Educación Común", o que aconteceria somente a partir de 1865. Ao produzir seus jornais dirigidos ao público feminino, Juana Paula Manso dependia da indeterminação de ser aceita pelo público e de ser financiada por aquelas que seriam as leitoras-alvo de sua produção: outras mulheres argentinas letradas e interessadas pelo saber como ela. Em seu trabalho, Graciella Batticuore chama a atenção para o fato de que a possibilidade de ser uma literata ou uma publicista na Argentina oitocentista dependeu sempre "del dinero y la aprovación masculina: la fortuna familiar, el subsidio estatal o la promoción del libro por parte de instituciones literarias" (2015, p. 155). A personagem não tinha patrocínios ou apadrinhamentos para projetos intelectuais como estes. Mais do que isso, ela era uma mulher separada e mãe de crianças pequenas as quais precisava sustentar e cuidar com seus próprios rendimentos. Não há, assim, como dissociar a situação da Manso-jornalista ao que, no século seguinte, Virginia Woolf relatou sobre as condições básicas que faltavam às mulheres escritoras de ficção e os impedimentos históricos que elas vivenciavam ao almejarem participar da cena letrada e do mundo editorial, mesmo que pertencessem às classes médias. Dividir o tempo e o espaço de produção com o mundo doméstico e familiar e não ter "condições de comprar mais que alguns cadernos de papel almaço por vez para escrever" (WOOLF, 2014, p. 102) são só alguns dos pontos que faziam com que as mulheres acabassem, muitas vezes, interrompendo suas carreiras, desistindo de publicar suas criações e silenciando.

${ }^{24} \mathrm{O}$ que pode até ter contribuído para "indiferença" das leitoras - será que elas se identificavam com a vida que levava Manso, a admiravam ou a almejavam, a ponto de sentirem empatia pela escritora? Sobre isso, é possível, ainda, fazer outras perguntas: será que essas mulheres tinham dinheiro e autonomia financeira para adquirirem e conservarem a assinatura do jornal ou da revista que gostariam de ler? Será que podiam escolher suas próprias leituras? Será que lhes desagradavam a postura e as temáticas abordadas por Manso, ou elas sequer conseguiam acessar, a priori, um jornal produzido por uma mulher, com o tom e a linguagem contida em "Album de Señoritas", de 1854, e em "La Siempre-Viva"?
} 
de Dios por la mañana y estudiando, meditando y escribiendo el resto del tiempo: es esto lo que me hace insistir tambien en pediros crónicas de salón, de tertulias, y en fin; cooperacion material à intelectual. Sereis tan indiferentes que no me correspondais de algun modo? No lo creo. Hay en mi, como una vago esperar que me infunde confianza. (LA SIEMPRE-VIVA, $\mathrm{n}$. 4, 09 jul. 1864 , p. 30)

Apesar de seu nome ter sido escolhido como uma referência a uma flor que deveria ser mais resiliente que a "flor del aire" ${ }^{25}$, o periódico "La Siempre-Viva" durou tanto quanto seu antecessor. Teve quatro edições, sendo encerrado de forma abrupta e sem grandes avisos em julho do ano em que foi lançado. Novamente, um semanário de Juana Manso desaparecia em razão do desdém do público e da falta de apoio e suas palavras e ideias de autora (e ativista) acabavam emudecidas na imprensa feminina. Conforme Francine Masiello, desde a queda de Rosas até 1870, difundiram-se em Buenos Aires os jornais escritos por homens sobre moda e o comportamento das mulheres - como o próprio caso de "La Flor del Aire" - que "a menudo proyectaban una imagen femenina dedicada a la domesticidad y a los asuntos del vestido; en algunos casos, se transformaban incluso en un medio para examinar las vidas privadas de las mujeres" (1989, p. 273). Neste contexto, as temáticas publicizadas e a linguagem politizada de Manso soavam como uma ameaça à nova ordem social pós-rosista, já que ela pretendia transformar as esferas domésticas e públicas ao defender a educação feminina, promover o acesso de suas conterrâneas a pautas que lhes eram negadas e reivindicar uma participação mais relevante da "madre republicana" na constituição e na vida da nação ${ }^{26}$ (AREA, 2005). Mas mais do que tudo, é preciso considerar que estes

\footnotetext{
${ }^{25}$ Essa era a justificativa para a escolha de Juana Manso ao alterar o nome do semanário de "La Flor del Aire" para "La Siempre-Viva": "[...] de todas las flores, es la Flor del aire á la par que una de las mas aromaticas, de menor duracion tambien. Flor del aire es el cariño que nacido ayer hoy muere sin preveer que acaso hiere para siempre un corazon! Perdonadme lectoras si en lugar de esa flor inconsistente, os ofrezco otra que emblema de mi pensamiento lo es tambien de duracion" (LA SIEMPRE-VIVA, n.1, 16 jun. 1964, p. 1).

${ }^{26}$ É preciso considerar que mesmo para os liberais, como os românticos que estiveram relacionados à Geração de 1837, a participação efetiva das mulheres ilustradas na esfera pública implicava "una nueva dimensión que no siempre estuvieron dispuestos a respaldar" (VICENS, 2017, p. 49). Ainda que a leitura feminina tenha sido uma preocupação de alguns daqueles homens desde fins da década de 1830, sendo promovida a partir de jornais como "La Moda" (1837) e romances como "Amalia" (1851-1852/1855), a
} 
argumentos vinham da pena de uma mulher: elas "“como devem ser' não falam de política" (PERROT, 2005, p. 321), o jornalismo "político e militante" não era considerado o seu lugar (AUZA, 1988, p. 195) ou tampouco as pessoas, em geral, estavam preparadas para conviver no espaço público com uma "intelectual ativa" como era Manso em meados do oitocentos (SOUTO, 2019, p. 153).

Nenhuma tentativa de silenciar Juana Paula Manso seria mais contundente e escancarada, no entanto, do que as que foram praticadas nos episódios ocorridos nos anos seguintes, os quais foram delineados na introdução deste artigo. Em 1865, ao tempo em que se tornava responsável pelos "Anales de la Educación Comun", a intelectual inaugurou uma nova forma de atuar na instância do público: a realização de "lecturas" nas quais falava para audiências sobre educação, história, religião, suas impressões sobre a sociedade norte-americana, dentre outros temas que considerava importante comunicar às suas conterrâneas e aos seus conterrâneos ${ }^{27}$. Investida de seu papel de "maestra" e estimulada por Domingo F. Sarmiento e outros sujeitos de letras, Manso realizou essas conferências em diferentes espaços e cidades da Argentina, mas nem sempre a sua presença e as suas palavras foram recebidas e ouvidas de forma respeitosa ou acolhedora. Ao contrário, como afirma Liliana Zuccotti, "las reacciones que genera son de una violencia y una irritación inéditas" (1994, p. 103). Logo na

ilustração das mulheres, em suas concepções gerais, é muito dirigida a moldar a conduta da mãe republicana e relacioná-la ao seu papel doméstico: ela deveria ser "capacitada para dialogar de igual a igual con su esposo y para educar a los hijos como ciudadanos de una república libre y democrática" (BATTICUORE, 2015, p. 51). Ressalto, assim, que por mais que mulheres escrevessem sobre temas como o casamento, a domesticidade e o vestir-se nos jornais femininos argentinos da década de 1860 - a própria Manso o fazia, como se pôde perceber -, a abordagem editorial feita pelos homens era bastante distinta, como afirma Masiello (1989). A autora destaca que a compreensão sobre os papeis e as representações das mulheres na sociedade, na construção da nação era disputada por mulheres e homens de letras nos jornais do período e que elas "forzaron los principios narrativos que ordenaban el espacio ideológico masculino, a través de su periodismo" (MASIELLO, 1989, p. 286).

${ }^{27}$ Segundo Graciela Batticuore, as "lecturas" de Juana Manso não eram exatamente uma prática comum para a época, já que ficavam no meio do caminho entre as leituras em voz alta em frente ao público dos ritos de caráter doméstico ou semipúblicos, que eram comuns na tradição portenha e americana - como as "tertúlias" e as "veladas literárias" - e a exposição oral, de caráter mais formal e acadêmico, que ocorria no seio das cátedras universitárias (2015, p. 139). 
segunda "lectura pública" da escritora em Buenos Aires, no primeiro semestre de 1866, um homem que compunha o público ouvinte lançou assafétida contra ela, tentando interrompê-la e constrangê-la ao marcar suas roupas com o odor da substância; Juana Manso falava, então, sobre a história e a cultura estadunidenses. O episódio causou comoção em Sarmiento. Em 17 de julho de 1866, ele remeteu uma carta de desagravo ao "Correo del Domingo", pedindo ao diretor do jornal que suas palavras constassem nas "columnas de su interesante publicación para dar una condigna satisfacción á Juana Manso, del vejamen que sufrió, mientras pronunciaba su discurso ó lectura sobre los Estados Unidos" (SARMIENTO, 1899, p. 137). Ali, o argentino ressaltava a qualidade da fala que sua conterrânea havia proferido, a qual, segundo ele, fora inclusive elogiada pela educadora Mary Mann: "[...] el discurso de Juana Manso es de hacer llorar á un norte-americano lágrimas de sangre. Es un milagro que una mujer creada en la América del Sud pueda escribir tales cosas [...] iQué asombrosa mujer es esta!” (SARMIENTO, 1899, p. 138), ela teria escrito para Sarmiento, referindo-se ao conteúdo da aula aberta ${ }^{28}$. Ao lamentar e indignar-se com o que havia ocorrido com Manso, o intelectual evidenciava que o ataque fora motivado por ela ser mulher. Dizia que a letrada havia sido "insultada en el acto de pronunciar un discurso, sobre materia que ninguna pasión rencorosa puede excitar" (SARMIENTO, 1899, p. 138) e que se, em geral, pessoas inteligentes e talentosas sofriam um "martírio prolongado" na Argentina oitocentista, a situação tornava-se "peor si es mujer, desvalida, impotente contra la opresión del desprecio ó de la indiferencia pública”, ao que completava:

Juana Manso ha visto transcurrir la vida sin que una mirada simpática haya vuelto hacia ella al oirla recitar sus versos. [...] ha tenido que ocultar su nombre de mujer y de poeta para acometer la continuación de los Anales; y cuando pronuncia una oración que deja asombrada á Mary Mann, que sólo

\footnotetext{
${ }^{28}$ Neste período, Mary Tyler Peabody Mann acabou estabelecendo uma relação profissional e de amizade com sua colega argentina, intermediada por Sarmiento e realizada a partir das correspondências que elas trocavam. Segundo Claire Emilie Martin, que analisou as correspondências enviadas por Manso para Mann, as duas "extraordinarias intelectuales" acabaram "unidas por las circunstancias y por el afán de promover la educación en sus respectivos países” (2012, posição 1390).
} 
palabras elocuentes y pensamientos profundos ha oído de Horacio Mann, Emerson, Pierce, Hill, y los grandes sabios de Cambridge y Boston, un hombre que lleva el vestido de los pueblos cultos le inutiliza el único vestido con que cuenta para salir á la calle, tal es su pobreza. (SARMIENTO, 1899, p. 139)

Em outra conferência de Juana Manso, em Buenos Aires, a intimidação ocorreu antes mesmo que ela iniciasse aquela que seria a sua "lectura" sobre a história das Reformas Religiosas na Europa. Na ocasião, segundo a própria professora ${ }^{29}$, entregaram-lhe "con aire misterioso una carta oficiosa, en que se me suplica el silencio sobre materias religiosas, anunciándome alli la aparición de un sacerdote para coartarme la palabra y delatarme al Obispo como hereje” (MANSO, 1866, p. 306). Ao relatar a iniciativa que lhe cerceou previamente a palavra, Manso perguntava: "Es una heregia la historia?" (MANSO, 1866, p. 306). É provável que a heresia residisse não só no tema da fala em uma sociedade que era marcadamente católica, mas, especialmente, no fato de que seria proferida em voz alta por uma mulher com espírito crítico (o conhecimento histórico, como já afirmamos, era considerado um saber masculino), dotada de ideias consideradas peculiares como a laicidade do ensino, além de convertida por vontade própria ao protestantismo. Este, no entanto, não foi o último esforço de silenciamento empreendido contra a intelectual em uma "lectura pública". O que aconteceu em Chivilcoy ficou marcado na história da personagem.

Entre 1866 e 1867, Juana Paula Manso iniciou um movimento para abrir a primeira biblioteca pública da Argentina naquela cidade, que havia sido uma das pioneiras no apoio e na implementação das reformas educacionais propostas por Sarmiento (PEARD, 2008, p. 466). Para divulgar a ideia entre a população local e

\footnotetext{
${ }^{29}$ Como já afirmamos, Juana Manso publicava nos “Anales de la Educación Común" textos de sua autoria em que refletia sobre o ensino na Argentina e a pedagogia, além de documentos produzidos por órgãos e agentes educacionais. Assim, ela editava e imprimia no periódico, também, narrativas e cartas escritas por si que se relacionavam com a temática e que contextualizavam acontecimentos experimentados por ela como docente, intelectual e funcionária do Departamento de Escuelas. É desta maneira que é possível acessar as memórias, as compreensões e os sentimentos de Manso sobre alguns dos episódios de silenciamento que vivenciou no exercício do magistério e como mulher pública relacionada com a pauta da educação.
} 
arrecadar recursos para construir o espaço físico e seu acervo de livros, a escritora passou a promover as suas conferências, bem como saraus literários e outras atividades culturais naquela comunidade. As duas primeiras "lecturas" de Manso em Chivilcoy, ambas sobre educação e as Escuelas Comunes, aconteceram sem sobressaltos. Já na terceira, ocorrida em abril de 1867, as reações contrárias surgiram. A intelectual havia, então, se preparado para ler ao público um drama de sua autoria intitulado "Rosas", teatro histórico ambientado no período do governo rosista ${ }^{30}$. Entretanto, assim como já havia ocorrido em uma das conferências de Buenos Aires, as tentativas de censura começaram em antecipação à sua fala. Conforme Juana Manso, na manhã do dia da conferência, ela soube "que se trabajaba abiertamente contra la lectura" (MANSO, 1866, p. 304), o que a fez cobrar dos membros da Comissão responsável pela Biblioteca, integrantes da municipalidade, sobre o que acontecia:

[...] me dirigí á la Comision de la Biblioteca encabezada por el Sr. D. Manuel Villarino, diciéndoles que si se dudaba del éxito de la lectura, yo por mi parte no tenía empeño en lucir mis habilidades; que si no querian que los recursos de la Biblioteca viniesen por mi mano, no insistiría tampoco en ofrecerlos, ni pecuniarios $\mathrm{ni}$ en colecciones de libros. La Comision me contestó verbalmente por su Secretario que la lectura tendría lugar. (MANSO, 1866, p. 305)

Garantida a realização do evento, ele foi iniciado. Ao começar sua apresentação, todavia, a intelectual logo foi interrompida:

Se habian introducido personas sin entrada, que apenas comencé á leer,
principiaron á pifiarme; yo suspendí y les hice presente que los que no
quisieren oir no eran obligados á permanecer allí, que yo no ponia nada en mi
bolsillo y venia solo á trabajar por el bien de la localidad. Fui invitada á
continuar por algunas personas y la tranquilidad se restableció. Con todo, la
barra impaga, no estaba tranquila, y breve tomaron el partido de apedrear por
fuera el edificio cuyas paredes y techos son de fierro. Era preciso terminar y
lo hice despidiéndome por largo tiempo de aquel pueblo cuyo vecindario no
culpaba sin embargo del desacato cometido. He sabido despues que unos han

${ }^{30}$ É possível que se tratasse do mesmo "drama histórico original" escrito por ela, intitulado "O dictador Rosas e a Mas-horca”, que foi apresentado no Theatro São Pedro de Alcântara, no Rio de Janeiro, em junho de 1853 (DIARIO, 7 jun. 1853, p. 4) 
dicho "Si queremos biblioteca no necesitamos que la Sra. Manso nos la dé". [...] Otros dicen que predico en mis lecturas la inmoralidad! (MANSO, 1866, p. 305)

A intimidação e a violência novamente eram recursos usados para interditar a voz de Manso; primeiramente, com zombaria e, depois, com o apedrejamento do prédio onde ocorria a conferência, o que a obrigou a encerrar definitivamente a leitura que fazia e despedir-se de sua audiência. É possível notar no relato da professora acima transcrito que o incômodo de alguns era, mesmo, com a presença e a postura públicas de Juana Manso, especialmente o ato de postar-se em frente a uma plateia e tomar a palavra para comunicar conteúdos que não eram relativos à esfera da domesticidade. Esta era, aliás, a compreensão de Domingo F. Sarmiento que, ao comentar com sua interlocutora o que ocorrera em Chilvicoy - não sem certa surpresa, por se tratar de uma localidade que havia sido, até então, receptiva aos projetos educativos dele e de Manso - afirmou: "Son las lecturas las que irritan" (SARMIENTO, 1899, p. 216). Se considerarmos que havia mulheres ouvindo a intelectual, as "lecturas" se tornavam ainda mais "imorais" ou "irritantes" para aquela sociedade. Ela mesma relatou que o público feminino que a prestigiava também era constrangido, sendo alvo de ofensas durante as conferências:

[...] un populacho grosero soportando el frio venía á apiñarse á las ventanas para proferir obsenidades dirigidas á las damas que asistian á mis lecturas, porque se les hace un delito en las mugeres hasta que deseen ilustrarse, y peor que delito es ridículo todavia en nuestro país que la muger haga uso de su inteligencia. (MANSO, 1866, p. 306)

Os ataques que Juana Manso sofreu por ser ilustrada, desejar que outras mulheres outrossim o fossem, e por "fazer uso de sua inteligência" publicamente - fosse produzindo escritos autorais que circulassem ou dando aulas e realizando "lecturas" abertas -, acabaram sendo realizados também por meio da linguagem, chegando até os jornais de Buenos Aires. No dia 29 de agosto de 1866, Enrique María de Santa Olalla um professor espanhol que, como ela, atuava em escolas primárias argentinas e que 
havia se tornado, há pouco mais de um ano, vice-diretor da Escuela Normal de Preceptores de Instrucción Primaria, Elemental y Superior - publicou em um diário portenho uma carta dirigida a Manso em que tentava não só excluí-la do discurso público, mas "alardear tal exclusão" ${ }^{31}$ (BEARD, 2018, posição 102). O teor do escrito era indisfarçadamente misógino e repleto da violência simbólica que é geralmente direcionada (mas não só) às mulheres que transgridam as normas socialmente definidas e que experimentam viver às margens do padrão socialmente aceito para elas. Em seu texto, Santa Olalla buscava desqualificar Juana Manso e suas intervenções a chamando, de forma condescendente, de "D. Juanita" e afirmando, em caixa alta, que ela tinha poucos saberes e habilidades intelectuais, que era uma espécie de pseudointelectual: " $E s$ Vd. lo que se llama una verdadera ERUDITA A LA VIOLETA" (SANTA OLALLA apud VELASCO Y ARIAS, 1937, p. 324). Isso porque, escrevia ele à letrada, "como educadora, ha probado Vd. su nulidad", “como 'escritora pública', está Vd. siendo la plaga de los periodistas, y el hazme reír de todos, cansados ya de oírla disparatar tanto" e como tradutora "se expresa Vd. en un lenguaje bárbaro que Vd. sola puede entender" (SANTA OLALLA apud VELASCO Y ARIAS, 1937, p. 324). O professor ainda dizia que sua colega dava "muestras visibles de desorganización cerebral que tan gravemente afectan sus facultades intelectuales" e que "siguiendo así, dentro de poco va a ser preciso amarrarla" (SANTA OLALLA apud VELASCO Y ARIAS, 1937, p. 324):

Tome, señora, tome por Dios algunos calmantes para atemperar la irritación de su sangre. Sus nervios están en una excitación muy alarmante, y forzoso es decírselo, su razón se halla en inminente peligro. - Tome mucha sanguinaria y procure combatir esa hidrofobia de que se halla atormentada, pues si hasta

\footnotetext{
${ }^{31}$ Enrique M. de Santa Olalla fundou, em 1867, uma revista chamada "La Escuela Primaria" sob os auspícios do Departamento de Escuelas. Entre 1869 e 1870, editou outro periódico, chamado "La Enseñanza", no qual voltaria a enfrentar Juana Manso, acusando-a, então, de "estrangeirizante" por sua relação com intelectuais e sua admiração pelas políticas educacionais norte-americanas (BATTICUORE, p. 141). Pela posição que ia assumindo naqueles anos, pode-se afirmar que, ao atacar Manso, Santa Olalla pretendia disputar com a personagem o espaço público no que se referia aos debates e às ações em torno da educação primária na Argentina.
} 
ahora derrama el veneno sin tasa con su pluma, disparatando tan desatinadamente, es de temer que cuando arrecien los calores, salga Vd. á mordernos, enloqueciendo con sus locuras a todo el mundo. - Y no crea Vd. que soy yo quien la califica de loca; es el público, que en mi concepto la conoce mejor que yo. (SANTA OLALLA apud VELASCO Y ARIAS, 1937, p. 324)

Chamar Juana Paula Manso de ignorante e de louca e ressaltar sua suposta irritação, sua raiva, sua irracionalidade e seu desatino foram, sem dúvida, estratégias de Enrique M. Santa Olalla para deslegitimar e anular a intelectual como sujeito público, o que fica mais evidente quando ele a acusa, como se fosse um problema, de ter "una sed insaciable que la devora por querer figurar" (SANTA OLALLA apud VELASCO Y ARIAS, 1937, p. 324). Como afirmam Maria Lígia Prado e Romilda Costa Motta ao tratarem de (outras) personagens latino-americanas que sofreram violência política, a mulher "que reivindica uma voz e exige ser escutada, desafiando o poder hegemônico é quase uma 'aberração", já que "ao fazê-lo, ela rompe com a dicotomia que a atrela ao âmbito privado, extrapolando uma visão de gênero que a configura como dócil, complacente e generosa" (2021, p. 34). Segundo as autoras, “a invalidação dela ocorre criando representações do outro oposto", sendo que "as imagens mais utilizadas passam pela noção de destempero - a mulher 'histérica', a 'degenerada', a 'louca' - lançando ataques, em muitas ocasiões, à sua sexualidade, à sua aparência e ao seu intelecto" (PRADO, MOTTA, 2021, p. 34). Ao longo de sua vida pública, Manso não foi poupada de praticamente nenhuma destas formas de hostilidade ${ }^{32}$.

\section{Considerações finais}

$\mathrm{Na}$ introdução deste artigo, salientei que em uma das cartas que enviou para Juana Paula Manso após os ostensivos ataques ocorridos contra ela em 1866 e 1867, Domingo Faustino Sarmiento a aconselhou a "baixar a voz" nas falas e nos escritos que

\footnotetext{
${ }^{32}$ Só a título de exemplo, em uma carta que já citei anteriormente, Sarmiento escreveu para a intelectual o seguinte: "Entre los suyos, continuará siendo la Juana Manso, una mujer gorda, vieja, pobre, es decir, nada ó poquísimo" (SARMIENTO, 1899, p. 141).
} 
faria adiante. Talvez tenha sido por essa razão - e para conseguir publicar depois de tantos insultos exteriorizados - que, em dezembro de 1867, ela tenha utilizado um pseudônimo, Violeta, ao começar a imprimir uma edição em espanhol de seu romance-folhetim "Misterios del Plata",33, ainda que esta fosse uma prática editorial que não parecia apreciar e nem costumava realizar, como autora assumida e "exhibida" (BATTICUORE, 2015) que era. Entretanto, nem as investidas dos antagonistas nem a sugestão do amigo levaram Manso a calar-se. Ela, inclusive, utilizou os "Anales de la Educación Común" para fazer circular as suas versões e respostas para as agressões que sofreu, editando, na publicação que dirigia, as missivas que enviou e recebeu sobre aqueles acontecimentos (as quais utilizei na análise acima realizada). Nos anos que seguiram, Juana Manso continuou tomando a palavra na arena pública, fosse conduzindo os Anales e escrevendo artigos para periódicos bonaerenses, como o " $\mathrm{La}$ Tribuna" e a "Revista Argentina", ou lecionando no ensino primário, reeditando seu Compendio de história e tornando-se, em 1869 e 1871, respectivamente, integrante do Departamento General de Escuelas e da Comisión Nacional de Escuelas ${ }^{34}$.

É importante ressaltar, pois, que por mais que esforços de silenciamento tenham ocorrido naquela esfera, realizados, especialmente, por sujeitos que pretendiam demarcar e preservar as suas fronteiras, não se pode pressupor que havia silêncio por parte das mulheres: muitas criaram estratégias para participar do espaço público, ainda que, em diversos momentos de sua trajetória, tenham sofrido com tentativas de exclusão. Ao longo deste texto, demonstrei algumas das vezes em que Juana Paula Manso se deparou com as mais diferentes formas de silenciá-la enquanto se inseria no universo letrado e intelectual da Argentina oitocentista. Também vimos que, sempre que podia, a escritora enfrentava as manifestações hostis e os obstáculos criados à sua

\footnotetext{
${ }^{33}$ Esta versão da obra foi intitulada por Manso de "Guerras civiles del Río de la Plata. Primera parteUna mujer heroica" e saiu no jornal "El Invalido Argentino" entre 1867 e 1868. A "segunda parte" não foi publicada pelo periódico.

${ }^{34}$ As nomeações, realizadas nos primeiros anos da presidência de Sarmiento sob o escândalo de alguns, fizeram de Manso a primeira funcionária pública mulher da Argentina (BARRANCOS, 2010, p. 110).
} 
produção autoral, à circulação de seus escritos e às suas "lecturas públicas", especialmente ao tratar de temas que, supostamente, não pertenciam ao escopo feminino e/ou eram considerados desviantes pela sociedade portenha. Nem sempre, no entanto, ela conseguia levar em frente projetos individuais, como os jornais dirigidos para mulheres que fundava, dirigia e cujas redações assumia. Nestas ocasiões, como provavelmente em muitas outras, sua condição de mulher (divorciada) e mãe, bem como a falta de apoio econômico e intelectual, faziam-na enfrentar a insegurança financeira e a sobrecarga de tarefas pelas quais passavam aquelas que, para produzir e imprimir seus textos originais, tinham que criar suas próprias possibilidades de ingresso no mercado editorial e publicista. Não é por acaso que ao relatar as agressões cometidas contra si nas conferências, Manso ressaltou a fragilidade de sua posição, a qual favorecia situações adversas como as que vivia: "Si yo tuviese un pedestal de oro pero pobre como soy y sola, es fácil echarme asafétida en la ropa y hacerme una ovacion de cascotazos!" (MANSO, 1866, p. 306).

Tornar-se maestra nas escolas primárias de Buenos Aires (a partir dos projetos educacionais promovidos por Sarmiento e Mitre, que tiveram seu apoio) foi a forma encontrada por Juana Paula Manso para ter um rendimento e uma profissão - podendo, assim, sustentar financeiramente não só sua família, mas também parte de suas atividades intelectuais - e para ocupar-se das discussões sobre educação e outros temas relacionados à formação da nação e da cidadania na Argentina. Mesmo sendo professora, limites foram impostos à sua atuação e produção, e escrever um manual didático de História quase foi um deles, como se demonstrou aqui. Segundo Liliana Zucotti, a violência institucional que Manso sofreu no Departamento de Escuelas se expressou também por meio de outros atos, como o "traslado de alumnos de su escuela, la negación de recursos, los informes de un inspector que la acusa de inmoral porque no enseña el catecismo" (1998, p. 368). A intelectual tinha consciência, no entanto, de que era por seu gênero que ela era impedida de falar mais, de fazer mais. Em uma carta 
que escreveu para a professora norte-americana Mary Mann, Juana Manso desabafou sobre isso; e tornou o desabafo público, em uma ação bem própria de quem aproveitava bem todas as arestas de oportunidade que lhe abriam para que fosse lida e ouvida, imprimindo-o nos “Anales de la Educación Común”:

Cree Vd. que yo puedo ser útil á mi país?Tal vez! Pero se renueva en mi la tragedia de Prometeo. Si la mujer en esta parte de América no estuviese condenada à la vida vegetativa. Si el haber nacido mujer no me inhabilitase para ejercer cargos públicos aun secundarios en la educación, yo también creo que hubiera podido con mi actividad; [...] pero no hay espacio en la esfera de la acción, y la tumba se abrirá en breves años para recibir la anciana inútil que gastó su vida en ilustrar su espíritu, en la mejora interna de si misma, suspirando debalde por que le permitiesen ejercer su salutar influencia sobre generaciones [...]. (MANSO, 1969, p. 15-16)

\section{Referências bibliográficas}

ALBUM de Señoritas, Buenos Aires, n. 1, 01 jan. 1854.

ALBUM de Señoritas, Buenos Aires, n. 5, 29 jan 1854.

ALBUM de Señoritas, Buenos Aires, n. 6, 05 fev. 1854.

AREA, Lelia. Álbum de Señoritas de Juana Manso: periodismo y frustración para un proyecto doméstico de fundar una nación. Buenos Aires: Feminaria Editora, 2005.

AUZA, Néstor Tomás. Periodismo y feminismo en la Argentina (1830-1930). Buenos Aires: Emecé Editores, 1988.

BARRANCOS, Dora. Mujeres en la sociedad argentina: una historia de cinco siglos. Buenos Aires: Sudamericana, 2010.

BATTICUORE, Graciela. La mujer romántica: lectoras, autoras y escritores en la Argentina, 1830-1870. Buenos Aires: Edhasa, 2005.

BEARD, Mary. Mulheres e poder: um manifesto. Tradução de Celina Portocarrero. São Paulo: São Paulo: Planeta do Brasil, 2018. E-book Kindle. 
BONAUDO, Marta (dir.). Nueva Historia Argentina. Volúmen 4: Liberalismo, estado y orden burgués (1852-1880). Buenos Aires: Editorial Sudamericana, 1999.

DIARIO do Rio de Janeiro, ano XXXII, ed. 153, 7 jun. 1853.

EPPLE, Angelika. Questioning the canon: popular historiography by women in Britain and Germany. In: PALETSCHEK, Sylvia (ed.). Popular historiographies in the $19^{\text {th }}$ and $20^{\text {th }}$ centuries: cultural meanings, social practices. Oxford/New York: Berghahn Books, 2013. E-book Kindle.

FRANCO, Stella Maris Scatena. Luzes e sombras na construção da nação argentina: os manuais de história nacional. Bragança Paulista: EDUSF, 2003.

FRANCO, Stella Maris Scatena. Viagens e relatos: representações e sociabilidade nos périplos de latino-americanos pela Europa e pelos Estados Unidos. São Paulo: Intermeios, 2018.

GRAU-LLEVERIA, Elena. La ficción política romántica en Los misterios del Plata. Episodios de la época de Rosas, escritos en 1846 de Juana Paula Manso. Decimonónica: Revista de Producción Cultural Hispánica Decimonónica, v. 7, n. 1, p. 1-20, 2010.

LA SIEMPRE-VIVA, Buenos Aires, n. 1, 16 jun. 1864.

LA SIEMPRE-VIVA, Buenos Aires, n. 4, 09 jul. 1864.

LEWKOWICZ, Lidia F. Juana Paula Manso, 1819-1875: una mujer del siglo XXI. Buenos Aires: Ediciones Corregidor, 2000.

MANSO, Juana Paula (ed.). Anales de la Educación Común. Volumen IV. Buenos Aires: Imprenta Americana, 1866.

MANSO, Juana Paula (ed.). Anales de la Educación Común. Volumen VII. Buenos Aires: Imprenta Americana, 1869.

MANSO, Juana Paula. Compendio de la Historia de las Provincias Unidas del Rio de la Plata. Desde su descubrimiento hasta la declaración de su independencia el 9 de julio de 1816. Destinado para uso en las Escuelas de la República Argentina. Buenos Aires: Imp. y Lit. á vapor, de Berheim y Boneo, 1862.

MARTIN, Claire Emilie. "My Dear Mrs. Mann": las cartas de Juana Paula Manso a Mary Tyler Peabody Mann y la educación de la mujer en América: In: MARTIN, C.; 
GOSWITZ; M. (ed.). Retomando la palabra: las pioneras del XIX en diálogo con la crítica contemporánea. Madrid/Frankfurt: Iberoamericana Editorial/Verveut, 2012. E-book Kindle.

MASIELLO, Francine. Angeles en el hogar argentino: el debate femenino sobre la vida doméstica, la educación y la literatura en el siglo XIX. Anuario del IEHS, Tandil, v. 4, p. 265-291, 1989.

MELO, Jeane Carla Oliveira de. Uma historiografia do esquecimento: o memoricídio e as práticas de escritura histórica de mulheres no século XIX. In: BUENOS, A.; ESTACHESKI, D.; ZARBATO, J. (orgs.). Ensino de História e Estudos de Gênero. Rio de Janeiro/Nova Andradina: Sobre Ontens/UFMS, 2020, p. 231-237.

MENDIETA, Alexander Betancourt. América Latina: cultura letrada y escritura de la historia. Barcelona/San Luis Potosí: Anthropos Editorial/Universidad Autónoma de San Luis Potosí, 2018.

MIZRAJE, María Gabriela. Argentinas de Rosas a Perón. Buenos Aires: Editorial Biblos, 1999.

MOGLIA, Raúl; GARCÍA, Miguel (ed.). Archivo Del Doctor Juan María Gutiérrez. Epistolario. Tomo VII. Buenos Aires: Biblioteca del Congreso de la Nación, 1990.

MUZART, Zahidé Lupinacci. Uma espiada na imprensa das mulheres no século XIX. Revista Estudos Feministas, Florianópolis, v. 11, n. 1, p. 225-233, 2003.

OLIVEIRA, Maria da Glória de. Os sons do silêncio: interpelações feministas decoloniais à história da historiografia. História da Historiografia, v. 11, n. 28, set-dez, p. 104-140, 2018.

PEARD, Julyan G. Enchanted Edens and nation-making: Juana Manso, education, women and trans-american encounters in Nineteenth-Century Argentina. Journal of Latin American Studies, v. 40, n. 3, p. 453-482, 2008.

PERROT, Michelle. As mulheres ou os silêncios da história. Bauru, SP: EDUSC, 2005.

POGGI, Marta Mercedes. Entre el pasado colonial y el estado-nación: la historia argentina en los libros escolares del siglo XIX. In: AMADORI, Arrigo; DI PASQUALE, Mariano (dir.). Construcciones identitarias en el Río de la Plata: siglos XVIII-XIX. Rosario: Prohistoria Ediciones, 2013. 
PRADO, Maria Ligia; MOTTA, Romilda Costa. Violência política contra as mulheres. In: PRADO, Maria Ligia (org.). Utopias latino-americanas: política, sociedade, cultura. São Paulo: Contexto, 2021, p. 19-36.

SABATO, Hilda. Historia de la Argentina, 1852-1890. Buenos Aires: Siglo XXI, 2012.

SARMIENTO, Domingo Faustino. Obras de D.F. Sarmiento publicadas bajo los auspicios del Gobierno Argentino. Tomo XXIX: Ambas Américas. Buenos Aires: Imprenta y Litografía Imprenta y Litografía Mariano Moreno, 1899.

SMITH, Bonnie G. Gênero e história: homens, mulheres e a prática histórica. Bauru: EDUSC, 2003.

SOUTO, Barbara Figueiredo. Mulheres e ideias impressas: projetos feministas de emancipação em periódicos do Rio de Janeiro e Buenos Aires (1852-1855). 2019. 319 f. Tese (Doutorado em História) - Programa de Pós-Graduação em História, Universidade Federal de Minas Gerais, Belo Horizonte, 2019.

TERLIZZI, Bruno Passos. História em pugna: a Revista del Río de la Plata no debate sobre a construção do campo histórico e literário argentino (1871-1877). 2019. $193 \mathrm{f}$. Tese (Doutorado em História) - Programa de Pós-Graduação em História, Universidade Estadual de Campinas, Campinas, 2019.

VARELA, Flavia Florentino. Maria Graham's Little Arthur's History of England (1835) and the female historian's place in early nineteenth century Britain. Women's History Review. DOI: 10.1080/09612025.2020.1751398, 2020.

VELASCO Y ARIAS, María. Juana Paula Manso: vida y acción, Buenos Aires, Porter, 1937.

VICENS, María. Entretenimiento, público y autoría femenina en los periódicos de Juana Manso (1850-1860). Perifrasis: Revista de Literatura, Teoría y Crítica, Bogotá, v. 8, n. 16, p. 48-63, 2017.

WOOLF, Virginia. Um teto todo seu. Trad. Bia Nunes de Sousa e Glauco Mattoso. São Paulo: Tordesilhas, 2014.

ZUCCOTTI, Liliana Patricia. Gorriti, Manso: de las veladas literarias a las "conferencias de maestra". In: FLETCHER, Lea (ed.).Mujeres y escritura en la Argentina del siglo XIX. Buenos Aires: Feminaria, 1994, p. 96-107. 
ZUCCOTTI, Liliana. Entre la pose y la palabra. In: DE MIGUEL, María Esther (ed.). Mujeres argentinas: el lado femenino de nuestra historia. Buenos Aires: Alfaguara, 1998, p. 363-379. 